E.-Deaths of RetiRed OfFicers - (contd.)

\begin{tabular}{|c|c|c|c|c|}
\hline No. & Rank & Name. & Date. & REMaRKs. \\
\hline 15 & " & T. Carey & 2 June & Hove, Brigh- \\
\hline $\begin{array}{l}16 \\
17 \\
18\end{array}$ & Surg."-Maj. & $\begin{array}{l}\text { A. Sharpe } \\
\text { T. W. Wright }\end{array}$ & 19 Aug. & \\
\hline $\begin{array}{l}19 \\
20 \\
21 \\
22 \\
23\end{array}$ & $\begin{array}{c}\text { Asst..'Surg. } \\
\text {," } \\
\text {," }\end{array}$ & $\begin{array}{l}\text { M. S. Grace } \\
\text { J. Murray } \\
\text { H. W. Hubbard } \\
\text { G. Lawson } \\
\text { Sir G. F. Duffey } \\
\text { R. J. B. Tunyn- } \\
\text { ghame }\end{array}$ & $\begin{array}{l}19 \text { April } \\
24 \text { July } \\
7 \text { Oct. } \\
12 \text { Oct. } \\
13 \text { Oct. } \\
23 \text { Dec. }\end{array}$ & $\begin{array}{l}\text { Wellington, } \\
\text { New Zealand. } \\
\text { London. } \\
\quad, \\
\text { Dublin. } \\
\text { Edinburgh. }\end{array}$ \\
\hline
\end{tabular}

\section{LONDON LETTER}

THE LONDON SCHOOL OF TROPICAL MEDICINE.

Sir Patrick Manson recently delivered an address at this school on "what it has done, is doing, and hopes to do." After referring in terins of warm laudation to the interest taken by the late Colonial Secretary, Mr. Joseph Chamberlain, in promoting education in tropical medicine and the hearty support given by the Seamen's Hospital Society to the starting and organisation of the Institution, he proceeded to give some particulars regarding its work and the contributions which have been made by its alumni to medical progress. Since the opening of the school on the 3rd of October 1899, 384 students have passed through it and obtained practical instruction in the nature, diagnosis and treatment of tropical diseases. Many of these students have carried with them the lessons learnt and methods of research taught to the field of their labours in tropical countries, and turned them to profitable acsount, while all of them have no doubt found the experience gained useful in practice. The statement of scientific work done by men connected with and trained in the school is highly creditable. It must not be forgotten that they have derived both inspiration and stimulus from Manson himself. The address has been published in extenso in the medical journals, and in abstract in the leading newspapers. It is given in full detail in the January number of "Climate," an excellent quarterly journal of tropical medicine edited by Dr. Charles F. Harford, the Principal of the Livingston College. This number gives some particulars regarding the history and work of the Liverpool School of Tropical Medicine and the institution over which he presides. This latter is intended to give medical instruction to missionaries. It was founded ten years ago. The curriculum extends over nine months, and con- sists of three courses of instruction in Anatomy and Physiology, Materia Medica, Medicine, Surgery and Therapeutics. Attention is also devoted to eye and skin diseases, tropical diseases, nursing and hygiene. The clinical training is obtained in selected Londun hospitals, and a laboratory has been fitted up for the use of students in the college building, which is residential. No doubt missionaries find the education thus obtained interesting and serviceable; but I am inclined to doubs whether a safe knowledge of inedicine can be attained in nine months, however enthusiastic the teachers and earnest the scholars.

It is curious to find that what professes to be a special educational number of "Climate" should omit all reference $t$ o the education in tropical diseases, which for the last forty years has been given in the Army Medical Schonl at Netley and is now being given in the Royal Army Medical College, London, and to the excellent work done by those who have passed through the Netley School.

\section{Superannuation.}

'The question of age-limit has cropped up in rather an acute form in the Edinburgh Infirmary. The practice in this institution is to elect the staff for periods of tive years--thrice renewable, and to assign wards for purposes of clinical instruction to certain University Professors. Recently the managers resolved to impose an agre-limit on their ordinary physicians and surgeons, and fixed this at sixty-five years without prejadice to present incumbents. This rule is a reasonable one and consistent with the practice of London hospitals. It accelerates promotion, introduces fresh blood and guards against senile incompetence or perfunctory attendance in consequence of pressure of private work. It is, moreover, in consonance with the tendency of the age. It may bear hardly on individuals in some cases, and seems to depreciate maturity and experience; but the rule is, on the whole, a sound an' grod one. At the annual meeting of the contributors to the Royal Infirmary, it was decided to "go one better" and apply the 65 years' limit to the University professors also. Now, seeing that there is no similar qualification regarding the tenure of the University chairs, the effect of the decision will be either to deprive the professor's of Mericine and Surgery of the power of giving clinical teaching to their students after they have attained the age of 65 , or to compel 
the University to make other and independent arrangements for clinical education. The position is somewhat anomalous and cannot obviously remain as it is. In the case of the professor of Clinical Surgery, the successor of Syme and Lister, who lectures in the Infirmary and holds the premier surgical appointment, it seems specially untenable. Moreover, the rule if rigidly carried out deprives the sick poor of Scotland of the privilege of obtaining the advice and services of the University professors, which has hitherto been exgerly sought and highly valued. I cannot help thinking and hoping that the new law will not, on reconsideration, be as the laws of the Medes and Persians.

\section{RADIUM.}

The marvels of radium continue to be the subject of lectures, newspaper and magazine articles, and of general curiosity and interest. A substance so rare and costly, that generates heat and light spontaneously and perpetually emits material emanations, and three descriptions of very penetrating rays, and exercises a destructive effect on organic tissue, cannot but excite wonder and stimulate imagination. The questions of most interest to medical men areCan its properties be turned to therapeutical use? Can its emanations and rays be employed for purposes of more exact diagnosis? Or can its destructive power over living tissues be so ordered that virulent microbes may be killed, while the tissues in which they are situated escape injury? Or can tissues of low organization and weak stability-embryonic or malignant-be dissolved while more mature and stable structures remain unaffected? These questions are at present in the stage of speculation, and can only be resolved by experimental research, but they seem to be very pertinent and important.

\section{Surgeon-General Sir William Roe Hooper K.C.S.I.}

This very popular and efficient officer relinquished on the 12th of January the office of President of the Medical Board at the India Office, to which he was appointed in succession to Sir Joseph Fayrer, Bart., nine years ago after a long and very meritorious career in the Indian Medical Service. The duties of this appointment include not only the examination of sick officers and of candidates for Indian services, but the delicate and responsible task of advising the Secretary of State for India on all questions of medical and sanitary administration. In both capacities Sir William Hooper was eminently successful. His thorough knowledge of Indian life and tropical diseases, combined with tact and kindliness, fitted him conspicuously for the duties of the Medical Brarl. The other duties were necessarily performed confidentially, and Hooper's share in the settlement of service questions, the selection of doctors and nurses in emergencies, and the disposal of the continual current of references which come from India regarding medical and sanitary questions, cannot be known outside of the India Office. Without betraying any confidences $I$ am in a position to state that his advice and assistance in these matters were highly valued, that he was loyal to his service and lost no opportunity of promoting its interests, and that his opinions were always well weighed, sound and judicious. He is succeeded by Colonel A. M. Branfoot, C.I.E., of the Madras Medical Service-the first Madrassee, as far as I know who has held this office. His Indian reputation is high, and there is every reason to believe that he will worthily fill a position which has been held by Martin and Fayrer, the duties of which, as Indian administration becomes more complicated and active, are undergoing a corresponding increase in weight and elaboration.

K. MeL.

20 th January, 1904.

\section{Cunrent đopits.}

\section{CEREBRO-SPINAL FEVER.}

Captain Robertson Minne, i.m.s, has returned to Kasauli and has resumed his investigation of Cerebro-spinal Fever. It is hoped that all Regimental Medical Officers, Civil Surgeons and Jail Superintendents will do what they can to help Captain Milne in this enquiry. Material from all cases of "Meningitis", whether cerebro-spinal or not, is required, and all officers who are likely to meet with such cases are invited to communicate directly with Captain Milne at the Pasteur Institute at Kasauli, who will send them instructions and the necessary apparatus.

\section{POLYPHARMACY IN PLAGIJE TREATMENT.}

THE following is an example of the way in which European medical treatment gets dis- 